\title{
Editorial \\ Nosso espaço de reflexão e debate
}

Veras, em latim, quer dizer "verdadeiras" - um qualificativo indicado para caracterizar palavras ou ações desta natureza, como o Aurélio consigna. E o fato de a palavra que nos dá título estar no plural aponta para uma característica inseparável do conhecimento, especialmente na área da Educação, onde pretendemos atuar como revista acadêmica a partir desta primeira edição: não há uma única verdade. Só os autoritários e os tolos acreditam na verdade única.

Mas há palavras e ações veras, no sentido de que buscam, por meio de diferentes pontos de vista e organizando suas reflexões a partir de variados autores, qualificar o trabalho docente, oferecendo reflexões ligadas a diferentes aspectos da relação ensino-aprendizagem e propondo debates sobre temas contemporâneos ligados ao vasto mundo educacional. Nada do que diga respeito à educação nos será indiferente.

Veras, esta publicação semestral do Instituto Superior de Educação Vera Cruz, de São Paulo, nasce com vontade de debater questões atualíssimas. Como o direito à educação, aqui presente em dois artigos. No assinado por Rosemeire de Araújo Rangni e Maria da Piedade Resende da Costa o que se debate é a (pouca) oferta de classes para crianças que demonstram altas habilidades. Fenômeno que chega a atingir de 3,5\% a 5\% das crianças, em escala mundial, a superdotação ainda permanece quase ignorada no país, a despeito da existência de políticas nacionais de educação especial prevendo a ação do Estado no sentido de prover recursos para esses alunos. Outra contribuição ao debate sobre alunos com necessidades especiais aparece no artigo de Marília Costa Dias, que traz uma síntese histórica das legislações, no Brasil e no mundo, abordando o direito à educação de crianças com deficiências - especialmente o esforço para integrá-las às classes regulares.

A contribuição de Márcia Vescovi Fortunato, sobre a questão da autoria na produção de textos, à luz da concepção formulada pelos postulados conceituais de Mikhail Bakhtin, investiga com especial atenção os processos de revisão, qualificando-os como um procedimento de autoria por excelência. 
A noção de autoria perpassa igualmente o artigo escrito por Maria José Nóbrega, que analisa algumas estratégias usadas por professores de alfabetização no processo de aprendizagem da escrita, todas compreendidas como etapas intermediárias rumo à afirmação plena e autoral de um texto. Partindo de exemplos escritos por crianças, a especialista demonstra como "tornando suas as palavras do outro, durante as atividades de transcrição, reprodução, decalque e autoria, espera-se que, ao longo da escolaridade, cada aluno desenvolva a autoria e, com ela, seu próprio estilo".

Especialmente recomendável a todo profissional que pretenda trabalhar com crianças no âmbito de pesquisas qualitativas em educação, o artigo de Renata Lopes Costa Prado discorre sobre as complexas relações entre pesquisador e pesquisado, demonstrando como os cuidados éticos em pesquisas dessa natureza precisam ser redobrados, especialmente em condições nas quais existam assimetrias de poder. E uma criança, em relação a seu entrevistador adulto, está em posição evidentemente desfavorável.

A necessidade de sermos críticos e reflexivos em relação às nossas práticas está presente também na colaboração de Magdalena Viggiani Jalbut. Seu objetivo é debater a formação teórica de docentes com vistas a formar profissionais que consigam refletir sobre sua prática ao mesmo tempo que exercem seu ofício de professor. Fazendo contraponto ao modelo da racionalidade técnica, a autora sugere 0 ensino das artes - que considera o aprender fazendo - como modelo de racionalidade prática no qual alunos e professores têm a oportunidade de refletir criticamente sobre a sua atuação.

Veras oferece, ainda, um interessante relato de experiência escrito por Mara Parisi de Moura sobre o projeto Ilha de Vera Cruz, que atua junto à população carente na modalidade EJA (Educação de Jovens e Adultos). 0 artigo faz um histórico da experiência e da metodologia envolvida na formação qualificada dos profissionais voluntários que estão envolvidos com o projeto. Por fim, a nossa seção de resenhas é inaugurada por Glória Kok, que comenta a obra da antropóloga francesa Michele Petit, Os jovens e a leitura - uma nova perspectiva (Editora 34).

Aos nossos autores, com os quais abrimos mais esta fronteira avançada da educação, nossos agradecimentos. Aos nossos leitores, tão novos quanto a própria revista, desejamos boas-vindas e boa leitura. E aos futuros autores antecipamos um convite: participem da próxima edição de Veras, que será publicada em novembro de 2011, submetendo seus artigos para avaliação do Conselho Editorial da revista até o final do mês de julho.

Ricardo Prado

Editor 